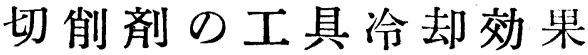

\section{——切削斉の冷却効果に関する研究 (2) 一}

正会員山本山明*

The Cooling Effect of the Cutting Fluid upon Tool.

\section{Akira YAMAMOTO.}

The cooling effect of the cutting fluid upon a tool was analytically investigated for an orthogonal cutting, by using an electrolytic tank which is formed as a tool model and made of a metallic plate having a surface resistance. In this analysis, a cooling power of fluid is represented by $h=\alpha / K$, where $\alpha$ is a heat transfer coefficient and $K$ a thermal conductivity of tool material, and for example $h$ would be $1 \sim 2 / \mathrm{cm}$ for water solution of oil or others under ordinary good conditions, but in case of a jet method it will be more than the above mentioned. A rate of heat transferred into fluid and machine body from tool top heat source $Q$ was given as a function of factors of cutting and tool conditions within the limit of usual ones. 55 70 $\%$ of this heat flow is absorbed in back rake surface, and 10 20\% in front clearance. And, the temperature distribution in tool becomes a concentrated one around the tool top source, making a sharp gradient, when $h$ increases more than 5 . The advancement of pouring device of emulsion is probably one of the best way to elevate the cooling power.

\section{1. 緒 言}

いわゆる切削剂を切削に用いるとき，及先温度低下は 潤滑効果を切離して考光るとき，切府，工具一機械系を 通じてうばわれる熱量に関係する。工具についてみる と, 単位時間に切削剂によつてうばわれる熱量 $Q$ は

$$
Q=\alpha A\left(\theta_{w}-\theta_{0}\right)
$$

で表わされ， $A$ は工具の袁面積， $\theta_{w}$ はその表面温度， $\theta_{0}$ は流体の温度， $\alpha$ は熱伝達率である。もちろん $\alpha, \theta_{w}$, $\theta_{0}$ は場所の函数として变化する。この式から明らかなよ うに冷却效果を増すためには

1. 切削剤の爇伝達率 $\alpha$ を上昇させる。局所熱伝详率 $\alpha$ はさらに工其の形状, 相対温度, また流動状態(もつ と実際的にいえば注油方法, 注油場所, 流速, 流量) 飞 関係するのである。

2. 切削剂の相対温度を低下させる。

3. 切削剂をもつとも 効果的な場所以集中一工具々 切首，仕上面の間に拥込むこ之，

が考学られよう。1、は切削㶡の性質の優劣にも大いに 関係するものであり，最近の Jet 注油法は 1，3を，ま た $\mathrm{CO}_{2}$ ガスによるもの (Ce De Cut法) はすべてをねら つたものといえよう。

この冷却効果に関する研究は，前報》にものべたよう

* 神戸大学工学部
に，切削斉の個々の性質を離れて，工具形状，切削条件 のうえから考察しようとするものである。そこで切削剂 の性質を注油条件も含めて熱伝達率 $\alpha$ で代表させ，電解 槽を利用して，色えな $\alpha$ に対して工具における冷却効果 を調べてみた。

\section{2. 実験の方法}

工具の冷却状態は定觉熱伝達であつて，かような闍題 は前報にものべたように, 電気的に電解槽或いは Analog 回路を用いて解くことが出来る。

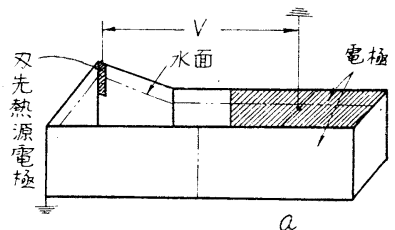

図1 の工具に相似 に拉大して作られた 木製電解槽は，刃先 熱源, 工具台への接 触面に相当する電極 および水面以外の工

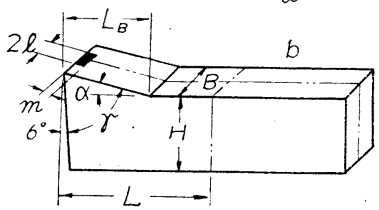

図 1 工具の対称牛分を扱い， 電極, 水面以外以抵抗板 で作り接地する。bにお いて $L_{B}=0.8 H \quad B=H$
具形状怟抗板でお

わわれる。こっで虫 水面を対称面とした 2 次元切削和ける 工具を考えることに する。この抵抗板の 厚さ方向の抵抗すな わち工具模型の表面 
国有抵抗 $r \Omega \mathrm{cm}^{2}$ は $1 / \alpha$, また水の国有抵抗 $\rho \Omega \mathrm{cm}$ は工 具の熱位導率 $K$ の逆数 $1 / K$ に対応する。また相対表面 熱伝達率 $h=\alpha / K$ 在考光る上，静電系では $\rho / \boldsymbol{r}$ となる 力.

$$
h=\alpha / K=C \rho / r
$$

にとつて $(C$ 模型倍率による係数 $)$ ，かつ工具に相似な 模型を作れば，工具におけると全く等価な状態が現出し よう。この扱いに拈いてなさ机る仮定は次のようにな 不。

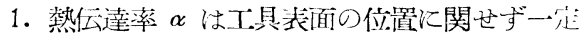

2.工其の熱性質は一尘

3. 刃先接触面と工具台接触面はいたる処で一走温度 にあるとし，後者は賞温と考え機械への吸熱能力は œとする。

\section{1 熱伝達率 $\alpha$, 相対表面熱伝達率 $h$ の推定}

切削の場に注がれる油剤はその附近の工具, 加工物,

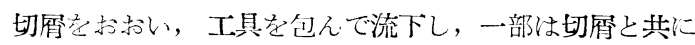
持去られる。この場合の流動状態は，噴流の衝突した附 近は乱流であり，これから遠ざかると層流に変り，遠方 ほど流速悱常に減ずるであるう。この解析は四難であ つて，さらに先熱源にごく近い場所での状態は明確で ない。しかし全体上して膜沸濤はないものとみなせ上 50

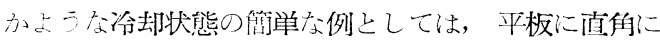

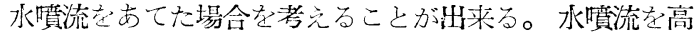
速で冷却面に衝突させる冷却方法は古くから登父凝結研 究に用いられ，高い局所熱位達率がえられるのである 方，多く法凝結側が主であるため冷却側についての军䮖 资料は極めて少ない。永井坁ら ${ }^{2)}$ が $100^{\circ}$ の蒸父で加熱 尤ている銅板儿 $24^{\circ}$ の水を坐径 $r_{0}$ の管から色々な速 度(レイノルズ数 $\left.R e_{0}\right)$ で噴出衝突させて， $\alpha$ を测定さ れているが，その最大佔は $0.6 \sim 0.9 \mathrm{cal} / \mathrm{cm}^{2} \mathrm{~s}^{\circ} \mathrm{C}$ となつ ている。そして $R e_{0}$ が大きいほど，また同じ $R e_{0}$ では 径の小さい管活ど $\alpha$ したがつて冷却效果怯大きい。かつ $\alpha$ は $1.25 r_{0}$ の位置で最大值をとり，衝突点から拡がつ て流速の小さくなるにつれて減じている。もつともこの 实験の $R e_{0}$ 快実際の注油状態に比して大きいし， $r_{0}$ も小 さいが，Jet 注油方式了ににていて，その等效果を裏 付讨万点が非賞に多い。

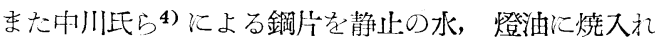
た場合に和汁る $\alpha$ の測定值も参考になる。 $\alpha$ は物体の形 で異り, 立方体では側面より角, 陵で大きい。 Leidenfrost 点で $\alpha$ は最大值をとるが，この值は水で約 2 ，燈 油で約 $1 \mathrm{cal} / \mathrm{cm}^{2} \mathrm{~s}^{\circ} \mathrm{C}$ であつて，うえのものより大きく出

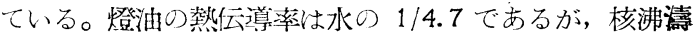
の部分での平均では $\alpha$ は $1 / 2.88$ となるのである。

さらに熱交換器にお打る熱通過摔の色々な值》）を参考 にすると，大きい估をとつてもう光の最大值の $1 / 10 \sim 1 / 4$ にすぎない。切削の場に打汁る油剤の流動状態明らか でなく，これら資料の条件とも一致しないので平均熱伝 達率 $\alpha$ を推定することは团難であるが，あとの図 2 に見 るように冷却が衝突点に近い所で行われることを考慮に 入れて，通常の注油条件で冷却状態がよい場合，水溶性 油で 0.2 の附近, 高压 Jet 注油方式で $0.8 \mathrm{cal} / \mathrm{cm}^{2} \mathrm{~s}^{\circ} \mathrm{C}$ の附近，不水浴性油でこれらの $1 / 3$ 以下と考えることに する。したがつて工具の熱伝導率 $K$ を $0.1 \mathrm{cal} / \mathrm{cms}^{\circ} \mathrm{C}$ と すれば，实験は $h=1 \sim 8 / \mathrm{cm}$ の附近で行えばよいことに なる。

\section{2 表面抵抗板}

抵抗としての色々な条件を考光種々の方法を試みた が，結局主に使用したものはトタン板に袁裏ラツカー吹 利けを行つたものである。抵抗したがつてラツカー被膜 の厚さを均一にするため, 各回每偟を变克て吹付け

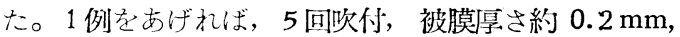
表酒回有抵抗 $r=0.125 \mathrm{M} \Omega \mathrm{cm}^{2}$ である。欲する $h$ をう るためには（2）式によりのを変化させる。をた及先熱源 の極板の縁とこれを包围与る抵抗板の縁が近いときに は，とくに $\rho$ が低い場合異常電流状態々なるので約 1.5 $\mathrm{mm}$ の間陑*存あけてある。

\section{3 測定方法}

電位分布，翼流電流の測定は前報々同じ方法で，後者 は公電圧法を朋いた。切削の咨際は流入熱量に関係する から，後都の結果は解㫋にのべたように，

$$
\theta / \theta_{0}=V_{I} / V_{I O}=I_{V o} / I_{V}
$$

から它電流法に直せ，工具条件を变化したときの及先温 度变化を考察出来ることも同じである。工具を形成する 各面要素への流入割合を测定するには，測定せんとする 面に電流計を入れ，他の面へは抵抗を入机て電流計によ る電圧降下を褞傥することによつて，これらを同じ電位 に拉いて測是した。

\section{3. 工具内における温度分布}

図 2 は这管状態に称ける，色々な $\boldsymbol{h}$ に対する工具内 の温度分布を示す。 $h$ の増加につれて温度分布は刃先に 偏在するようになり， $h$ が5以上ともなると，温度勾配

*工具模型は 10 倍に作られているから，実際寸法で は0.15mmである。油剤が冷却能を落すことなく， 材料の流れに逆つて，熱源にどれだけ浸入または 接近出来るかは明瞭でない。 

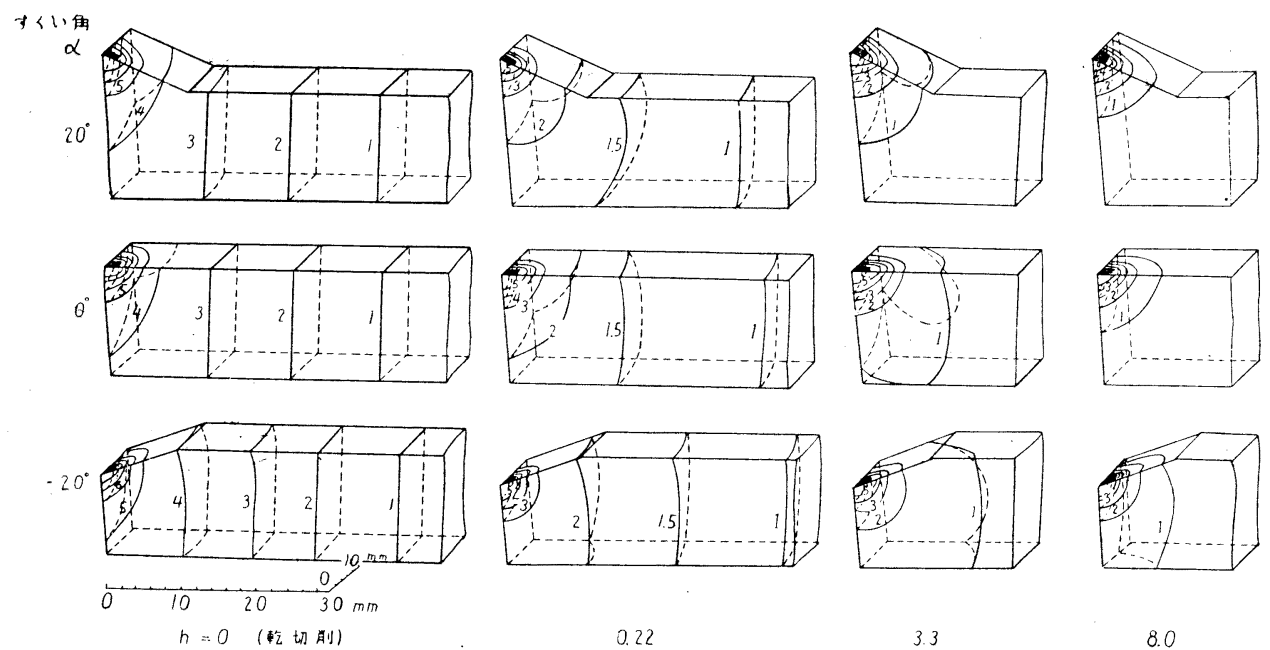

0.22

3.3

8.0

図 2 及先温度を 10 , 切制剂と工具台接触面温度を 0 としたときの温度分布。2 次元切创に打ける対称牛 分を示し，手前は中心面，前飞げ角 $6^{\circ}, L=47, H=15,2 l=4, m=2(\mathrm{~mm})$

は急であつても分布のうえでは大差はなくなる。この成 から，次のことが云えよう。

1. 現存の不水溶性, 水溶性油は, も乙その性能とく 飞注油方法を改善出来るならば，冷却能を変えうる余地
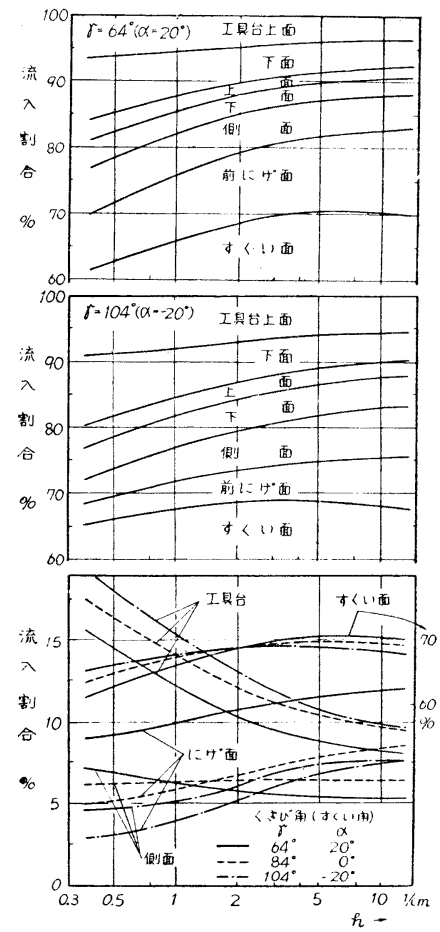

図 $3 H=15, L=1.5 H$ $2 l=4 \quad m=2$
㤝分ある。 2 .

冷却能の大きいと き, 図のように工。 具全体を冷却しな くても, Jet 注油 法のように要所を 冷却するだけで流 量少くして效染を あげうる。(实際 のように前にげ面 に入れるときは戍 と分布状態は晎る が) 3.しかしこ の場合には，注油 中の注油条件の変 動は夕先比熱的龟 裂を生ずる危険性 が多い。4.hの 変化につれて工具 面でうばわれる熱 量割合は変化す る。(次節)

\section{4. エ具各面に流入する熱量割合}

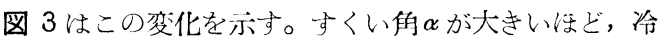
却面が近くかつその面積も大きいので，すくい面，前に げ面に入るものが多くなる。とくにすくい面で大きいの は土其全体が冷却され熱流が 工具台方向晌うことによ る。さらに $h$ が大となると，前にげ面，側面に入るもの が増すことは明白であろう。また $h$ の大きいとき前節の 2. の上うに工具柄附近の冷却が招ろそか、なつてもよ いといえる。図は附記条件の場合であるが， $l, m, H$ を 増加するとすくい面に入るものがや〉増し，例壳ば $H=$ 10 では 55～65\%となつて前にげ面流入量が増す。

\section{5. 冷却能, 工具条件と叉先冷却効果}

任意の $h$ をうるには実験では $\rho$ を変えたが， $L_{V}$ が $\rho$ に逆比例することを利掤して，o一这のもとで $h$ を変化 したときの先加ら流れる 全實流電流 $I_{V}$ を求めること が出来る。図 4 は $\rho=1000 \Omega \mathrm{cm}$ としたときの变化を六 したもので， $h$ を増してゅくと备面への流入割合は図3

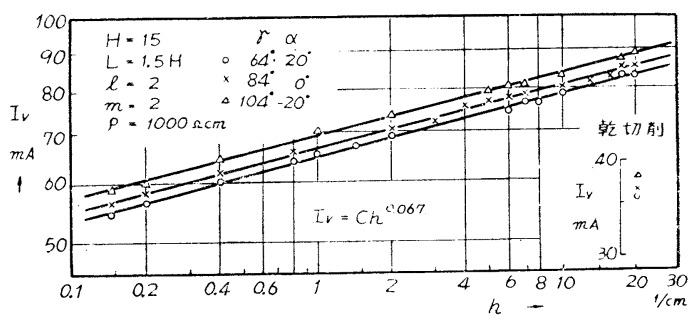

図 4 
のように変化しても，全体としては図4のような関係で 増加するのである。現存の油剤の冷却能力は工具全体に 対しては, 乾切削化扮计る最大值 (前報, 工具台の吸熱

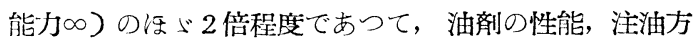
法によりて $h$ が変化しても向上の余地はうばえる熱量の 美ではたかだか 40〜50\%以下にすぎないのである。むし 万3節の 2. のように量少くして效果をあげる方法を考 亲るべきであろう。

网は㖘り出し辰さ $L=1.5 H$ のときであるが， $L=C$ 1 〜3) $H$ の実験の範用では $I_{F}=C(H / L)^{0.02}$ の関係が成 立する。よつて以下 $L=1.5 H$ について报い，実際に多 くとられる条件の範用で考劣，かつこの範用で影響度の 少ない因子は省略することにする。

図 5 は $h=3, H=15$ の場命飞扮いて, 双物角 $r($ に
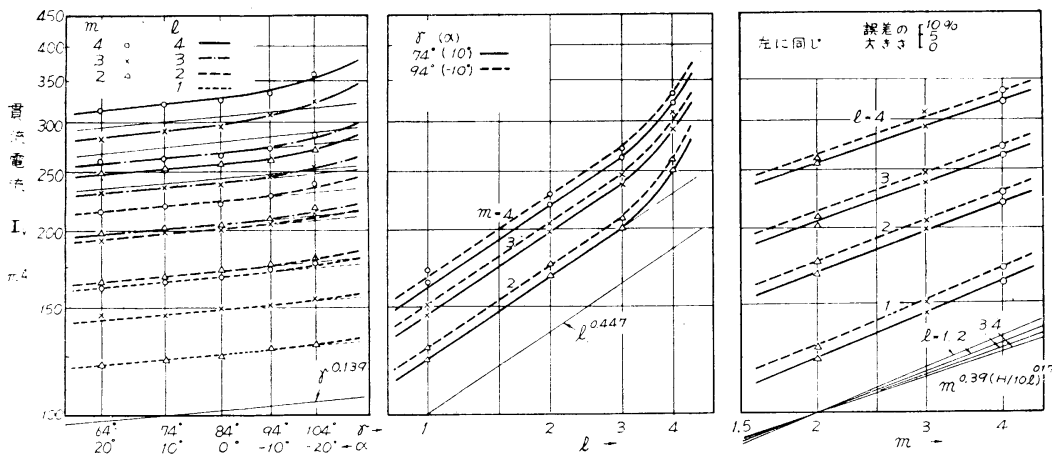

図 $5 h=3, H=15, L=1.5 H, L L_{B}=0.8 H$ ることが出来た。
くい面上でらめる大きさ関保するともい兄る。これら を整理して，普通条件の範用で次のように約士 $2 \%$ 精 度で近似することが出来た。

$$
\begin{aligned}
n & =0.48\left(L_{B} / H\right)^{0.92}(H / 10 l)^{0.17} \\
& =0.325 L_{B}{ }^{0.92} l^{-0.17} H^{-0.75}
\end{aligned}
$$

$L, L_{B}, l, m \odot H$ に対する相似比, $r, h, \rho$ が同じ ならば， $H$ の変化飞対して $I_{V}$ がある一迆の法則てした がつて变化することは当然である。これらの同じ組合せ に対し $H$ について整理したところ，多小のバラッキが あるが近似的に $H=10 \sim 20$ の範用で $I_{\mathrm{r}}=C H^{1.71}$ とす

以上ををとめ， $\rho$ を工具の熱云導率 $K ， I_{V}$ を刃先温 度を一定汇保つたときの熱通過量 $\boldsymbol{Q}_{\theta}$ に怙きかえて

$$
\begin{gathered}
Q_{\theta}=C_{\theta} h^{0.07} H^{1.71} \bullet \\
\gamma^{0.14}\left(\begin{array}{c}
H \\
L
\end{array}\right)^{0.02} \cdot \\
\left(\frac{l}{H}\right)^{0.45}\left(\begin{array}{c}
m \\
H
\end{array}\right)^{n} K
\end{gathered}
$$

さらに $Q_{\theta}$ を $I_{V}$ とみなし (3)式を利用して，工其への 流入熱量を $\partial Q$ とし, 工具条 件拉よび冷却能を変化した場 合の及先温度の变化を考察出 来る。(5) 式より

$$
\begin{aligned}
& \theta_{t}=C_{Q} \quad \dot{o} Q \alpha^{-0.07} \text {. } \\
& K^{-0.93} \quad H^{n-1.29} \text {. }
\end{aligned}
$$

げ角 $6^{\circ}$ としたときのすくい角 $\alpha$ ), 切㰌幅 $2 l$, 切属上 $\gamma^{-0 \cdot 14} L^{0 \cdot 02} l^{-0 \cdot 45} m^{-n}$

の接触上さｍの変化にともなう $I_{\Gamma}$ の変化を示したもの である。この $I_{V}$ は工具の対象坐分の模型で这電圧 $10 \mathrm{~V}$

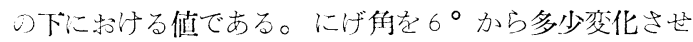

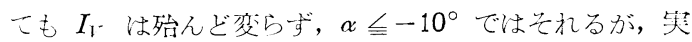

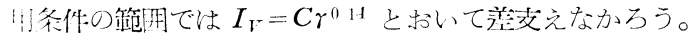
切原幅 $2 l$ の変化沈は， $m$ の大きさもや子関係するが，

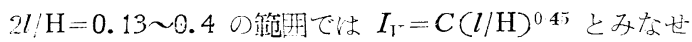
る。だ゙し $2 l \geqq H / 2$ となると側伯による冷却効果があ してきて，この関係から先れて失うことが咸にみられ え。

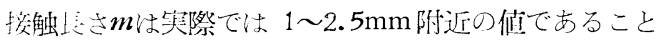
ボ多いが，实䮖では極，上抵抗板之の间附を約 $1.5 \mathrm{~mm}$ に 上つたのでこの影響をさけるため $m=2$ 以上の值で行 つた。 $I_{V}$ は $I_{V}=C(m / H)^{n}$ と榬わせが，べき $n$ は $l$ およびすくい面の投影よさ $L_{B}$ の影響をうけ， $l / H$, $m / L_{B}$ が大となるとつれ $n$ 以減少する。これ恃熱源がす
この式は，普通にとられる条件の範用で，切削剂を使用

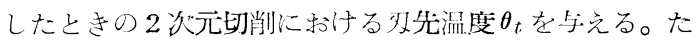
ベし $L_{B}=0.8 H$ で, $n$ は（4）式で与光られ，この精度 は土5\%位であうう。 $o Q, L$ 以外の増加はすべて $\theta_{t}$ を

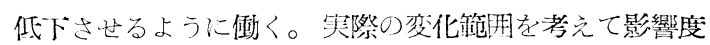
の高いものは核が $\delta Q$ (切削条件) $, l, \alpha, H$ といつた徂 であ万う。また解報の乾切削の場全と比べて， $H, l$ の 影㒨がまし， $L ， \gamma$ の影響が減ることは冷却の状態から みて明白なことである。さらに(6) 式に㧍ける常数 $C_{Q}$

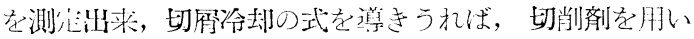
た場合の切削滥度の理詇汁算が行えるようになるう。

\section{6. 総 括}

1. 切削殽の冷却性能（性質上注油条件）を $h$ で代表 さ也, 2 次元切削に対し, 電解槽を利用して, 工具 内温度分布, 工具备陑への流入敖合, 工具条件の及 
先温度への影響を澗べた。

2.工具が広範囲で邻却される場合，50\%以上の熱が すくい面で奪われる。つずいて前にげ俑である。

3. $h \geqq 5$ 以上では温度上昇は风先のごく近傍に限ら れて, 分布のうえでは大きな変化はみられなくなる。

4. 同じ良好な注油条件では 水溶性油に比し不水溶性 油の熱伝達率は $1 / 3$ 以下とみてよからうが，てれが 5 倍ちがつても工具から奪いうる熱量は 20\%程度の 养にすぎない。

5.よつて冷却性能のよい切削剂を用い，注油条件， 場所をえらび，あるいは熱源近くへ押込んで，量少 くして切削剂の出しうる最大の效果をあげることを ねらうべきである。例えばJet 注油法の如きである。
6. 工具条件を変化したときの双先温度は（6）式で表 わせる。影響度の多い因子は $o Q, \alpha, l, H$ などで ある。

(1956, 2月24日受付)

\section{参考交献}

1) 精密機械: 22, 6 (昭31) p. 273 .

2) 永井, 河合, 谷口: 機峨学会論文集, 21, 104 （昭30） p.310.

3) R. J.S. Pigott : Am. Machinist, Jan. 21(1952). 倉田忠雄：日立造船技埌，16，2(昭30-5) p. 43. 4) 中川, 吉田：機峨学会論文集, 18,72（昭 27) p. 16.

5) J. H. Perry : Chemical Engineers' Handbook

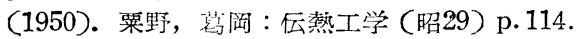

\section{高速切㓱の研究（第 9 報）}

一一接触面積理論に基づいた切削速度効果について一

$$
\text { その } 1
$$

正会員竹山秀 彥*

Study on High Speed Machining (9)

Cutting Speed Effect based upon Theory of Tool-Chip Contact Area-_ (Part 1)

By Hidehiko TAKEYAMA

It was reported by the previous papers that the tool-chip contact area is a controlling factor in metal machining. One of the most typical examples of this effect is revealed in high speed machining.

The main object of this experiment is to find out the reason why the machining characteristics are such improved that the shear angle and chip thickness ratio increase, and the cutting force decreases generally, when cutting speed is raised up. By such a special type of machining test that the shear angle was always kept constant, it was proved that the shear strain in the shear plane is localized into a narrow zone as the cutting speed increases. This is because that the plastic deformation in the shear zone occurs more adiabatically at higher cutting speeds as C. Zener made it sure in his punch test of rather plastic materials. Anyhow this tendency makes the tool-chip contact area smaller at higher cutting speeds, which results into a larger shear angle, that is, better machining characteristics, to balance the cutting force on the rake face, according to the theory described by the previous reports.

Here also so called the coefficient of friction in metal cutting has been proved to be a poor index of the machining characteristics, whereas the tool-chip contact area has been demonstrated to play a very important role in the mechanism of high speed machining as well as for the analysis of general metal machining.

\section{I. 緒 論}

前報1)に括いて，及面切屑接触面積が切削性を左右す
る支配的要素なることを示したが，その間の関倸が最も 端的炕あられれ 且つ実際上非常江重要な意味をもつ例が 高速切削である。本報告江扮いては，黄銅，鋼及び鋳鉄 